Original Research Article

\title{
A study to evaluate the analgesic activity of Origanum vulgare in mice using tail flick method
}

\author{
Siddhi Raveendran ${ }^{1}$, Vikram Rajadnya ${ }^{2} *$, Revati Kothari ${ }^{1}$, \\ A. V. Tilak ${ }^{1}$, Sayan Das ${ }^{1}$, Rahul Bhalsinge ${ }^{3}$
}

Department of Pharmacology,

${ }^{1}$ Dr. D. Y. Patil Medical College and Hospital, Pune,

Maharashtra, India

${ }^{2}$ Dr. D. Y. Patil Medical College

and Hospital, Kolhapur,

Maharashtra, India

${ }^{3}$ L. N. Medical College and Hospital, Bhopal, Maharashtra, India

Received: 08 July 2019

Revised: 10 August 2019

Accepted: 11 September 2019

*Correspondence to:

Dr. Vikram Rajadnya,

Email: med.pharma@dpu.edu.in

Copyright: () the author(s), publisher and licensee Medip Academy. This is an openaccess article distributed under the terms of the Creative Commons Attribution NonCommercial License, which permits unrestricted noncommercial use, distribution, and reproduction in any medium, provided the original work is properly cited.

\begin{abstract}
Background: Pain is a complex experience consisting of physiological and psychological response to a noxious stimulus. Analgesics like opiates and nonsteroidal anti-inflammatory drugs are commonly used for relieving pain but are associated with various unwanted side effects; therefore this study was conducted by using Origanum vulgare for their analgesic efficacy.

Methods: In vivo model used was tail flick method. Origanum vulgare ( 84 $\mathrm{mg} / \mathrm{kg} \mathrm{p.o)} \mathrm{was} \mathrm{administered} \mathrm{in} \mathrm{mice.} \mathrm{The} \mathrm{analgesic} \mathrm{activity} \mathrm{was} \mathrm{studied} \mathrm{by}$ recording the reaction time after administration of the drug at frequent intervals up to 3 hours. The results were analysed by ANOVA and Tukey's test. P value $<0.05$ was considered as significant. Pentazocine showed statistically prolongation in the reaction time after $30 \mathrm{~min}$ as compared to Origanum vulgare.

Results: In tail flick method, pentazocine showed statistically significant increase in the reaction time after $30 \mathrm{~min}$ of administration as compared to control group. However, Origanum vulgare in a dose of $84 \mathrm{mg} / \mathrm{kg}$ showed significant increase in the reaction time after $30 \mathrm{~min}$ of administration as compared to control group. On comparing pentazocine and Origanum vulgare, pentazocine showed highly significant increase in the reaction time after $30 \mathrm{~min}$ as compared to Origanum vulgare at $84 \mathrm{mg} / \mathrm{kg}$ dose.

Conclusions: From the present study, it was concluded that extract of Origanum vulgare exerted analgesic activity in both the models. However, it was less potent than pentazocine. Thus, Origanum vulgare can be used in mild to moderate painful conditions.
\end{abstract}

Keywords: Analgesia, Origanum vulgare, Pentazocine, Tail flick method

\section{INTRODUCTION}

Pain is an enteroceptive sensation which warns of the danger of bodily harm and alerts to trauma and injury. Analgesia commonly known as painkillers is used by number of patients who seek treatment of pain which is the most important therapeutic objective of any analgesic. However, half of the patients using analgesics seem to be dissatisfied with available pharmacological options. ${ }^{1}$ In addition, many of these drugs cause serious side effects. The adverse effect profile associated with opiates (like pentazocine) consist of physical dependency, tolerance and addiction while that of non-steroidal antiinflammatory drugs (like paracetamol) consist mostly of gastrointestinal disorders. ${ }^{2}$

It is known that herbal plants with medicinal properties have been used since ancient times which show potent analgesic activity with minimal adverse effects. ${ }^{3}$

Origanum vulgare, a traditional medicine, is known to have various properties like diuretic, stimulant, antimicrobial, anti-inflammatory, antioxidant and anticancer. ${ }^{4}$ Several studies have reported that Origanum 
vulgare has potent analgesic activity, so this study was conducted to evaluate analgesic efficacy of Origanum vulgare compared to pentazocine using tail flick method in mice.

\section{METHODS}

The study was commenced after Institutional animal ethics committee approval was granted and is conducted in accordance with Committee for the purpose of control and supervision of experiments on animals guidelines. ${ }^{5}$

\section{Study animals}

Experimentally naive mice were selected for the study. Swiss albino mice, experimentally naive of either sex, weighing 18-22 gm were selected for study. The mice were procured from animal house of Dr. D. Y. Patil Medical College, Hospital and Research Centre, Pune-18.

\section{Study population}

The study was conducted on 24 Swiss albino mice; 8 mice in each group.

\section{Study period}

The study was conducted from January 2018 to June 2018.

\section{Animal feed}

Food

Mice were fed with commercially available 'Nutrimix Std-1020' manufactured by Baramati Agro Ltd, acquired from Nutivet Life Sciences, Pune. The nutrition provided by the pellet feed was contained energy $3620 \mathrm{kcal} / \mathrm{kg}$, crude protein $22.15 \%$, crude fibre $62.48 \%$, ash $5.11 \%$ and sand silica $1.15 \%$.

\section{Water}

Drinking tap water supplied by Pimpri Chinchwad Municipal Corporation was provided to the mice through the feeding bottles with stainless steel nozzle in each cage. Food and water were replenished once daily in the morning.

\section{Animal housing}

Mice were housed in groups of four in standard big polypropylene cages under standard condition of temperature $\left(25 \pm 5^{\circ} \mathrm{C}\right)$ and relative humidity $(55 \pm 10 \%)$ and 12/12 hour light or dark cycle. Apart from daily replenishment of food and water, they were left undisturbed.

\section{Study drugs}

Origanum vulgare (leaf extract; Jesus Heals Ayurveda Centre, Pune) was used as test drug.

Pentazocine (from Pharmacy, Dr. D.Y. Patil Medical College, Pimpri, Pune) was used as standard analgesic drug used in study. Pentazocine solution was freshly prepared in distilled water and given in a dose of 1.4 $\mathrm{mg} / \mathrm{kg}$ i.p.

\section{Study design}

Mice were divided into three groups consisting 8 in each group.

Table 1: Groups showing drugs and dose.

\begin{tabular}{|ll|}
\hline Groups & Drugs and dose \\
\hline I & Distilled water $(1 \mathrm{ml}$, i.p. $)$ \\
\hline II & Origanum vulgare $(84 \mathrm{mg} / \mathrm{kg}$, i.p. $)$ \\
\hline III & Pentazocine $(1.4 \mathrm{mg} / \mathrm{kg}$, i.p. $)$ \\
\hline
\end{tabular}

\section{Methods for evaluation of analgesic activity}

\section{Screening}

Prior to employing different methods to study the analgesic activity, a preliminary screening was done. Those mice showing reaction time of less than 15 seconds were included in the study. ${ }^{6}$ Analgesic activity of aqueous extract of Origanum vulgare was studied with help of tail flick method: widely used to evaluate opioid analgesics.

\section{Procedure}

Mice weighing 18-22 $\mathrm{g}$ were used and placed into small cages, leaving the tail exposed. The tail of the mice was held gently. A light beam was focused (exerting radiant heat) to the proximal third of the tail. The mice tried to pull the tail away and rotated its head, a reaction known as escape reaction. The test drug and standard drug were administered intraperitoneally.

The same procedure was repeated and the reaction time was noted after 30, 60, 90 and 120 mins.

A lengthening of the reaction time was interpreted as an analgesic action of the test drug. At each time interval those mice that showed higher reaction time than the time before drug administration were regarded as positive. ${ }^{6,7}$

\section{Statistical analysis}

The data was compiled and analyzed with the help of statistical package, Primer of biostatistics, version 7.0. Results were expressed in mean and SD were analysed using one-way repeated measures analysis of variance 
(ANOVA) followed by Tukey's test for multiple comparisons and $\mathrm{p}$ value $<0.05$ was considered to be statistically significant.

\section{RESULTS}

Figure 1 shows the results of analgesic activity of Origanum vulgare and pentazocine as compared with control. Origanum vulgare in a dose of $84 \mathrm{mg} / \mathrm{kg}$ showed statistically significant prolongation in the reaction time after 60 min of administration.

However, on comparison, we see that in tail flick method, pentazocine showed statistically significant increase in the reaction time after $30 \mathrm{~min}$ of administration as compared to the control group.

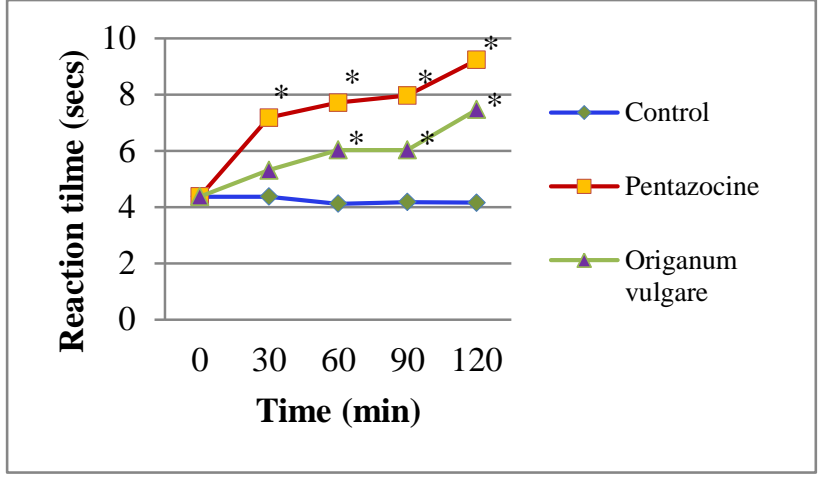

Figure 1: Reaction time in different groups.

*: Comparison of Origanum vulgare and pentazocine with control group $(\mathrm{p}<0.05)$.

Table 2: Results of tail flick method.

\begin{tabular}{|c|c|c|c|c|c|}
\hline \multirow{2}{*}{ Groups } & \multicolumn{5}{|c|}{ Time in min (mean \pm SD $)$} \\
\hline & 0 min & $30 \mathrm{~min}$ & $60 \mathrm{~min}$ & $90 \min$ & $120 \mathrm{~min}$ \\
\hline Control & $4.37 \pm 1.68$ & $4.37 \pm 1.68$ & $4.12 \pm 1.27$ & $4.18 \pm 0.92$ & $4.16 \pm 0.96$ \\
\hline Origanum vulgare & $4.37 \pm 1.68$ & $5.31 \pm 0.51$ & $6.03 \pm 0.86^{*}$ & $6.03 \pm 0.86^{*}$ & $7.47 \pm 0.78^{*}$ \\
\hline Pentazocine & $4.37 \pm 1.68$ & $7.18 \pm 1.66^{* \#}$ & $7.71 \pm 1.23^{* \#}$ & $7.96 \pm 1.12^{* \#}$ & $9.23 \pm 1.28^{* \#}$ \\
\hline
\end{tabular}

*: Comparison with control group ( $\mathrm{p}<0.05),{ }^{\#}$ : Comparison with Origanum vulgare $(\mathrm{p}<0.05)$.

Figure 2 shows comparison of pentazocine and Origanum vulgare, where pentazocine showed highly significant increase in the reaction time after $30 \mathrm{~min}$ as compared to Origanum vulgare at $84 \mathrm{mg} / \mathrm{kg}$ dose.

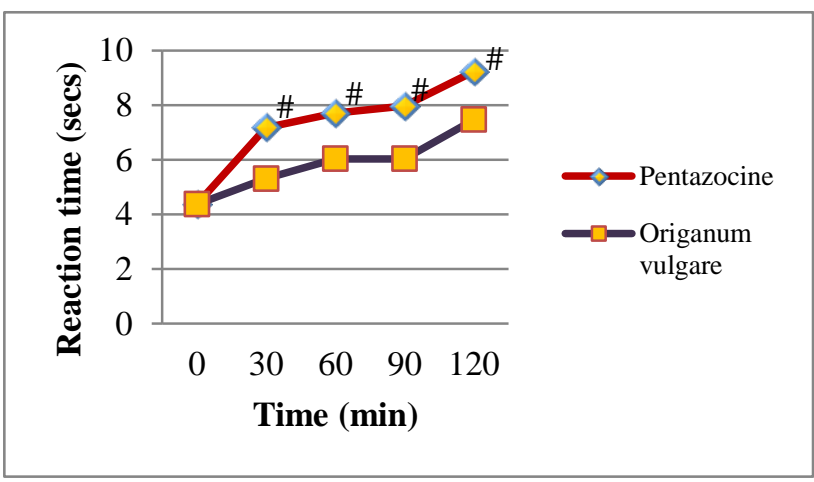

Figure 2: Comparison of reaction time in pentazocine and Origanum vulgare treated groups.

\#: Comparison with Origanum vulgare $(\mathrm{p}<0.05)$.

The analgesic activity of Origanum vulgare was statistically less significant than pentazocine at as seen in the above graph but it was statistically more significant than the control group at all time intervals.

\section{DISCUSSION}

Pentazocine is a potent opiate analgesic which is used to relieve pain and apprehension caused due to it. However, it is associated with various adverse effects so there is a need to find a novel drug having similar analgesic activity with minimal adverse effects.
The present study was carried out by using tail flick method to evaluate the analgesic activity of aqueous extract of Origanum vulgare compared to that of pentazocine.

The results of the present study suggest that Origanum vulgare exhibits significant effect at dose $84 \mathrm{mg} / \mathrm{kg}$ i.p. compared to the control but when the analgesic effect of Origanum vulgare was compared with pentazocine, it exhibited significant analgesic effect as compared to Origanum vulgare.

Thus, the findings of the present study are similar to the findings of study done by Arzi et al. The latter evaluated the hydroalcoholic extract of Origanum vulgare in rats by formalin test where maximum analgesic effect was seen at a dose of $600 \mathrm{mg} / \mathrm{kg}$. This analgesic effect of Origanum vulgare was less than analgesic affect exhibited by aspirin (300 $\mathrm{mg} / \mathrm{kg})$ and morphine $(2.5$ $\mathrm{mg} / \mathrm{kg})^{8}$

Another study done by Khaki et al evaluated antinociceptive activities in aqueous extract of Origanum vulgare using tail flick test. ${ }^{9}$

It is reported that the analgesic effect of Origanum vulgare can be attributed to the compound named carvacrol. Carvacrol has an inhibitory effect on prostaglandins. Inhibition of prostaglandins cause antinociception. $^{10}$

In the present study, Origanum vulgare showed statistically significant increase in reaction time after 30 mins of administration as compared to control group. 
However, pentazocine showed statistically significant increase in reaction time after 30 mins compared to control and Origanum vulgare.

Isolation, purification and characterization of active compounds of the extract were not a part of this study. Further such studies are needed as the active compound may be better in efficiency as compared to standard analgesic drug.

Also, the combination of standard drug with Origanum vulgare has not been studied. It might be possible that its extract potentiates analgesic activity of standard drugs which may result in lowering of dosages and helps in minimizing the undesirable effects of such drugs.

Further, toxicity studies and clinical trials are needed to establish it as a drug in mild to moderate painful conditions.

\section{ACKNOWLEDGEMENTS}

I would like to acknowledge Jesus Heals Ayurveda Centre, Pune and Dr. D. Y. Patil Medical College Pharmacy, Pimpri, Pune for graciously providing me with my study drugs Origanum vulgare and pentazocine respectively.

Funding: No funding sources

Conflict of interest: None declared

Ethical approval: The study was approved by the Institutional Animal Ethics Committee

\section{REFERENCES}

1. Craig AD, Sorkin LS. Pain and analgesia. Available at Encyclopedia of Life Sciences. (C) 2001 Nature Publishing Group. www.els.net. Accessed 2 October 2008.
2. Hanson GR, Venturelli PJ, Fleckenstein AE. Drugs and Society. 10th ed. Boston, USA: Jones and Bartlett; 2009.

3. Vitthalrao AM, Shanbhag T, Kumari MK, BerryKL, Shenoy S. Evaluation of anti-inflammatory and analgesic activities of alcohol extract of Kaempferia galangal in rats. Indian $\mathbf{J}$ Physiol Pharmacol. 2011;55(1):13-24.

4. Duka JA. Handbook of medicinal herbs. Maryland, USA: CRC Press; 2002: 243.

5. CPCSEA guidelines for laboratory animal facility. Chennai: CPCSEA. Available at: icmr.nic.in/ bioethics/final_cpcsea.pdf. Accessed on 2 October 2008.

6. Gupta R. Analgesic agents. In: Gupta SK. Drug Screening Method. 3rd ed. New Delhi: Jaypee Brothers Medical Publishers; 2016: 476-497.

7. Ghosh MN. Fundamentals of experimental pharmacology. 6th ed. Kolkata: Hilton and company; 2015: 46.

8. Arzi A, Aghel N, Khorasgani ZN, Motahari M. The study of analgesic effect of hydroalcoholic extract of Origanum vulgare in rat by formalin test. Toxicology Letters. 2009; 189:105-115.

9. Khaki MRA, Pahlavan Y, Sepehri G, Sheibani V, Pahlavan B. Antinociceptive effect of aqueous extract of Origanum vulgare L. in male rats: possible involvement of the GABAergic system. Iran J Pharm Res. 2013;12(2):407-13.

10. Silveira S, Andrade LN, Sousa DP. A review on antiinflammatory activity of monoterpenes molecules. 2013;18:122754.

Cite this article as: Raveendran S, Rajadnya V, Kothari R, Tilak AV, Das S, Bhalsinge R. A study to evaluate the analgesic activity of Origanum vulgare in mice using tail flick method. Int J Basic Clin Pharmacol 2019;8:2254-7. 